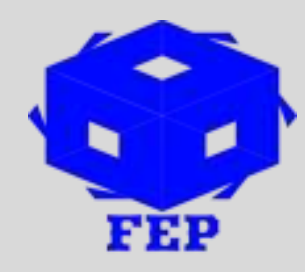

\title{
THE EFFECTS OF JOB CHARACTERISTICS ON EMPLOYEE'S ORGANIZATIONAL CITIZENSHIP BEHAVIOR AMONG BANKING SECTOR EMPLOYEES IN PESHAWAR CITY
}

Muhammad Adil ${ }^{1}$, Muhammad Haroon ${ }^{2}$, Muhammad Zakar ${ }^{3}$, Mian Jawad Shah ${ }^{4}$, Muhammad Tahir ${ }^{5}$ ${ }^{1,2,3,4}$ BBA Alumni, Business Administration Department, Iqra National University, Pakistan

${ }^{5}$ Business Administration Department, Iqra National University, Peshawar, Pakistan

*Corresponding Author: Muhammad Adil

Corresponding Author Email: adilkaka98@ gmail.com

Article Received: 11-05-19 Accepted: 30-05-19

Published: 10-06-19

Licensing Details: Author retains the right of this article. The article is distributed under the terms of the Creative Commons Attribution-NonCommercial 4.0 License (http://www.creativecommons.org/licences/by-nc/4.0/) which permits non-commercial use, reproduction and distribution of the work without further permission provided the original work is attributed as specified on the Journal open access page.

\begin{abstract}
The objective of the study was to measure the relationship between job characteristics and organizational citizenship behavior among banking sector employees. The study was conducted in the banking sector in the city of Peshawar. The research methodology used is quantitative approach and survey for data collection. Through sampling, we generated a sample of 60 respondents belonged to the six different banks. Our results indicate that task significance and autonomy has significant influence on staff OCB; while, results for skills variety, task identity, and feedback turned out to be insignificant. The five dimensions of job characteristic model together explained $27.8 \%$ change in the dependent variable of employee OCB. Our results support the previous studies finding that OCB is influenced by job design.
\end{abstract}

Keywords: Job Characteristics, Organizational Citizenship Behavior, Banks, Peshawar

\section{INTRODUCTION}

Organizational citizenship behavior (OCB) refers to the voluntary behaviors exhibited by the employees during stay in the organization as good citizen of the organization. Organizational citizenship behavior (OCB) become popular since the term was introduced in the late 1980's by Organs who is known as the father of Organizational citizenship behavior (OCB). In 2006 Organ presented five factor dimensions model which are conscientious, sportsmanship, civic virtue, courtesy and altruism. Job characteristic model is proposed by Hackman and Oldham (1980) and is based on five dimensions including skills variety, task identity, task 
significance, autonomy, and feedback. The purpose of this study is to explore the relationship between five dimensions of job characteristics and their influence on employee's OCB. The study is conducted in the banking sector in the city of Peshawar.

\section{Problem Statement}

The main problem this study is investigating is the low level of employee OCB observed among the banking sector employees. The current study investigates this problem using the job characteristic model. Our problem statement is as follows. "Investigation of influence of job characteristic model on employee's OCB'

\section{Research Question}

What is the effect of job characteristics on the employee's OCB in the banking sectors in Peshawar, Pakistan?

\section{Objectives of the Study}

The objectives of the study are given below.

- To measure the effects of skill variety on the employee's OCB

- To measure the effects of task identity on the employee's OCB

- To measure the effects of task significance on the employee's OCB

- To measure the effects of autonomy on the employee's OCB

- To measure the effects of feedback on the employee's OCB

\section{Significance of the Study}

The significance of the study is that it contributes the literature by highlighting the role of job design and job characteristic model as predictor of employee's OCB. The contribution of this study for the practitioners is that employee's OCB can be enhanced using the finding of the study.

\section{LITERATURE REVIEW}

\section{Organizational Citizenship Behavior}

The term "Citizenship" as behaviors is introduced by organ and Bateman first time in 1983. They argue that employee citizenship behavior play vital role in an effective organizational functioning. Organ, MacKenzie, Podsakoff (2006) delivered an extended review of OCB and defined it as individual behavior that is discretionary, not directly predictable by the formal reward system and that in the aggregate stimulates the effective operations of the organization. OCB is optional in nature and goes far beyond the outdated requirements of the job (Smith, Organ, \& Near, 1983). Podsakoff and MacKenzie, (1997) explains this characteristic using helping a co-worker as an example. He stated that helping a coworker influence result in a dysfunctional situation for the employee, but when many of employees involve in such behavior constantly it will improve organizational effectiveness. Since the introduction of the term "organizational citizenship behavior" by Bateman and Organ (1983), researchers have recognized almost thirty different forms of Organizational Citizenship Behavior (OCB) (Podsakoff, Bachrach, Pain, \& MacKenzie, 2000). Although different labels have been used for the dimensions of OCB, there is an undisputable connection among categorizations. The organization of this sector is mostly haggard by following Podsakoff and associates' review (2000) that discussed OCB by taking into account its related concepts such as pro-social organizational behavior (POB), organizational spontaneity (OP), and contextual performance $(\mathrm{CB})$. Different categorization are introduced by various experts including 
Podsakoff, MacKenzie, Paine, and Bachrach (2000), Smith, Organ, \& Near, (1983), Organ, (1988). In this study, we are using the categorization scheme mentioned by Podsakoff, MacKenzie, Paine, and Bachrach (2000). Details are as follows.

\section{Conscientiousness Behavior}

Conscientiousness consists of behaviors that go well beyond the minimum role requirements of the organization (Law, Wong, \& Chen, 2005). These behaviors indicate that employees accept and adhere to the rules, regulations, and procedures of the organization. If the employee highly conscientious that implies that he/she is highly responsible, obeying rules and required less supervision (Podsakoff and Mackenzie, 1997). Conscientiousness is one of the overarching dimensions of Organizational citizenship behavior OCB.

\section{Sportsmanship Behavior}

Sportsmanship is defined as willingness to tolerate the inevitable inconveniences and impositions of work without complaining (Organ1990). According to Podsakoff and Mackenzie (1997) good sportsmanship would improve the moral of the employees at the workplace and subsequently reduce employee turnover. Employees who engage in sportsmanship are described as people who not only do not complain when they are disturbed by others, but also maintain a positive attitude even when things do not go their manner (Podsakoff and Mackenzie, 1997).

\section{Civic Virtue behavior}

Civic virtue is a behavior on the part on an individual that indicates that employee dutifully participates in extra activates, attending meetings, and concerned about the life of the company (Podsakoff, et al., 2000). Civic virtue represents macro-level interest and commitment to the organization. Podsakoff et al., (2000) describe civic virtue as a person's acknowledgement of being part of a larger whole in the same way that citizens are members of a country and accept the responsibilities.

\section{Courtesy Behavior}

Courtesy behavior refers to the evading involving or contributing in behaviors that are harmful to one's organization and to the society. According to Neuman \& Baron (1998) courtesy behavior is about "Do not hurt" or more specifically "Do no harm through action". While this dimension is according to the current conceptualization included in the dimension of "serving" (Organ, Podsakoff and MacKenzie, 2006).

\section{Altruism Behavior}

This dimension was originally labeled "altruism". It was given a new name, because "altruism" was criticized to indicate selflessness as a motive overdue the behavior and limited the dimension thereby to those movements which were inspired by selfless motivators (Organ, MacKenzie, Podsakoff 2006). The original conceptualization is defined as voluntarily helping others with, or avoiding the amount of work related problems. (Podsakoff, et al., 2000). Heilman \& Chen (2005) states that on gendered expectations, woman are expected to engage in altruistic and courteous more than men.

\section{Job Characteristics}

In 1980 Hackman and Oldham's Job Characteristics theory is the highest recognized model of job design. The Job Characteristics Model (JCM) has been the most widely mentioned model in the work design literature, and many other theoretical extensions were created on or influenced by this model (De Varo, Brookshire, \& Li, 2007). The JCM framework is based 
on the effects of job characteristics, such as skills variety, task identity, task significance, autonomy, and feedback on employee outcomes such as satisfaction, performance, and motivation. The aspects of job variety allow the employees to utilize a number of different skills for executing the task effectively in the work place. Job identity allows the employees to take ownership and accomplished the task at hand. The job significance provides the employees an insight of how much important the job for them and for the organization as well as how their work are positively contributing in the society. Autonomy relates to the opportunity of freedom one has in his/her job, the employees has the freedom of performing the work in their own way, how they feel better they can do their work by their own style. Lastly, feedback is that dimension of the job characteristics which describes the performance of the job to the employees (Chiu \& Chen 2005).

\section{Relationship between Job Characteristics and Organizational Citizenship Behavior}

Although there are several studies on the antecedents of OCB, the literature includes relatively fewer studies on the relationship between job characteristics and OCB (Chiu \& Chen, 2005). This relationship has been studied in fewer studies (e.g. MacKenzie, Podsakoff, \& Bommer, 1996; Farh, Podsakoff, \& Organ, 1990). For example, Farh and associates in 1990 studied the OCB and stated that it is the most related action of direct effect of job characteristics on OCB. They argued that to the degree that task characteristics encourage intrinsic motivation, and must directly influence OCB. What is meant by intrinsic motivation is employees performing different jobs just for sake of enjoyment and do not expect any rewards in return. Farh and associates presented two reasons for the direct effect of job characteristics on OCB. The first one is intrinsically motivating tasks create a sense of responsibility, one of the required psychological states that should be present

(Hackman \& Oldham, 1980). Therefore, employee would feel personal accountability for that particular job. Second direct effect of intrinsically motivating tasks increase meaningfulness of the job, it means that employee get satisfaction that he/she contributing for the welfare of the society and his/her job is meaning full, it is also another psychological state. This improved meaning of the job and realize the relations among his/her associates in terms of interdependence (Farh, Podsakoff, \& Organ, 1990). Those employees who have intrinsically motivating jobs that create a feeling of personal responsibility and enhance the meaning of the job would show organizational citizenship behavior and work in a way that help the interests of their organization as a whole and help their coworkers. To demonstrate, employees that assemble motor car breaks are more likely to pay careful attention to their work because they are aware of the tragic consequences.

Organ and associates in 2006 argued that the feedback provided by the job itself is most direct, most correct, the most self-assessment evoking and the most intrinsically motivating source of feedback. They recommend that job feedback would be strictly interrelated to helping others with job related problems, and creating productive ideas about how to improve job performance. In a study conducted by Podsakoff and MacKenzie (1997) positive correlation between job feedback altruism and conscientiousness is identified. In the present study our focus is on how each job characteristics factor is related to organizational citizenship behavior.

\section{Hypothesis}

Hypotheses of the study are as follows. 
$\mathrm{H} 1=$ Skills variety is significantly related to OCB.

$\mathrm{H} 2=$ Task identity is significantly related to OCB.

$\mathrm{H} 3=$ Task significance is significantly to OCB.

$\mathrm{H} 4=$ Autonomy is significantly related to OCB.

$\mathrm{H} 5=$ Feedback is significantly related to OCB.

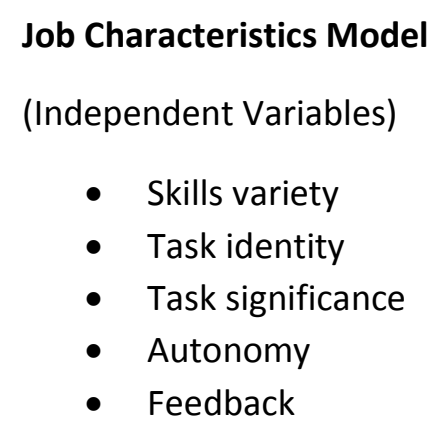

\section{Research Nature}

\section{RESEARCH METHODOLOGY}

The nature of the study is quantitative. The quantitative approach is chosen because it is suitable for the nature of our topic and the research question and objectives.

\section{Population}

The population of this research is from Bank sector of Peshawar Pakistan. As a whole were the employees of Silk Bank, Summit Bank, Sunehri Bank, Bank Alfalah, Faysal Bank, Habib Bank.

\section{Sample and Sampling Technique}

Because population is large and is unable to collect data from all the population, therefore, we used the sampling approach. Convenience sampling technique which is part of nonrandom sampling was used to fill the questionnaire. The questionnaires are filled from 6 different banks.

\section{Data Collection Procedure}

We collected the data through questionnaires and distributed these questionnaires in 6 different banks of Peshawar which includes Summit bank, Habib bank, Bank Alfalah, Silk bank, Faysal bank and sunehri bank. The questionnaire was distributed among qualified staff like manager, cashier, accountant, consultant and others.

\section{Data Analysis Technique}

Data is analyzed using the descriptive statistics and regression analysis using the SPSS version 20.

\section{RESULTS}

In our sample, there were 43 male and 17 female. 17 participants belonged to the age category of 20 to 25 years; 19 participants in 26 to 30 years; 11 participants in 31 to 35 years; 9 participants in 36 to 40 years; 2 participants in 46 to 50 years; and 2 participants in 51 to 55 years age category 
Table 1

Demographic Details

\begin{tabular}{|c|c|c|}
\hline & Frequency & Percentage \\
\hline \multicolumn{3}{|l|}{ Gender } \\
\hline Male & 43 & 71.7 \\
\hline Female & 17 & 28.3 \\
\hline \multicolumn{3}{|l|}{ Age } \\
\hline $20-25$ & 17 & 28.3 \\
\hline $26-30$ & 19 & 31.7 \\
\hline $31-35$ & 11 & 18.3 \\
\hline $36-40$ & 9 & 15.0 \\
\hline $46-50$ & 2 & 3.3 \\
\hline $51-55$ & 2 & 3.3 \\
\hline \multicolumn{3}{|l|}{ Bank } \\
\hline Alfalah Bank & 17 & 28.3 \\
\hline Habib Bank & 11 & 18.3 \\
\hline Silk bank & 10 & 16.7 \\
\hline Suneri Bank & 6 & 10.0 \\
\hline Faysal Bank & 10 & 16.7 \\
\hline Summit Bank & 6 & 10.0 \\
\hline \multicolumn{3}{|l|}{ Role } \\
\hline Managerial & 16 & 26.7 \\
\hline Cashier & 19 & 31.7 \\
\hline Accountant & 4 & 6.7 \\
\hline Consultant & 5 & 8.3 \\
\hline Others & 16 & 26.7 \\
\hline
\end{tabular}

Bank wise, 17 belonged to the Alfalah bank, 11 belonged to the Habib bank, 10 belonged to the Silk bank, 6 belonged to the Suneri bank, 10 belonged to the Faysal bank, and 6 belonged to the Summit bank. Job role wise, 16 belonged to the managerial role, 19 belonged to the cashier role, 4 belonged to the accountant role, 5 belonged to the consultant role, and 16 belonged to the others category.

\section{Regression Analysis}

Regression is used for testing the effects of job characteristics model on employee organizational citizenship behavior. Results are as follows.

Table 2

Regression Analysis- Results

\begin{tabular}{|c|c|c|c|c|c|}
\hline \multirow[t]{2}{*}{ Model } & \multicolumn{2}{|c|}{ Unstandardized Coefficients } & \multirow[t]{2}{*}{ Standardized Coefficients } & \multirow[t]{2}{*}{$\mathrm{t}$} & \multirow[t]{2}{*}{ Sig. } \\
\hline & B & Std. Error & & & \\
\hline (Constant) & 4.424 & .370 & & 11.960 & .000 \\
\hline Skills Variety & .048 & .074 & .097 & .643 & .523 \\
\hline Task Identity & -.120 & .066 & -.317 & -1.822 & .074 \\
\hline${ }^{1}$ Task Significance & .170 & .082 & .322 & 2.068 & .043 \\
\hline Feedback & -.047 & .083 & -.108 & -.567 & .573 \\
\hline Autonomy & -.244 & .091 & -.479 & -2.698 & .009 \\
\hline $\begin{array}{l}\mathrm{R}=.527 \\
\text { Rsquare-= .278 } \\
\text { Adjusted Rsqurae= }\end{array}$ & & & & & \\
\hline
\end{tabular}


The Rsquare value shows that job characteristic model explains $27.8 \%$ change in the dependent variable of employee's OCB. Coefficient results shows that skill variety has positive but insignificant effects on the employee's $\mathrm{OCB}(\beta=.048, \mathrm{P}<0.05)$. Task identity has negative but insignificant effects on the employees OCB $(\beta=-.120, P>0.05)$. Task significance has positive and significant effects on the employee's OCB $(\beta=170, \mathrm{P}<0.05)$. Feedback has negative but insignificant effects on the employee's OCB $(\beta=-.047, \mathrm{P}>0.05)$. And autonomy has negative and significant effects on the employee's OCB $(\beta=-.244$, $\mathrm{P}<0.05)$. Based on these results, we can say that we accept hypothesis number 3, and 5; while, reject the hypothesis number 1,2 , and 4 .

\section{CONCLUSION}

The data for the research is collected from six Banks of private sector located at Peshawar, Pakistan with the objective to observe the relationship of job characteristics and organizational citizenship behavior. Our results shows that task significance and autonomy plays important and significant role in shaping employee's organizational citizenship behavior. Previous studies results also shows that job characteristic model explains OCB including Farh, et al., (1990); and MacKenzie, et al., (1996). Overall, our results are consistent with the findings of previous studies. On the basis of our results, we can conclude that job characteristics and job design are important factors which shapes employee's OCB.

\section{Recommendation}

- It is recommended that banks may improve employee's OCB by better design of the jobs.

- It is recommended that employees task significance may be increased since it can positively lead to employee's OCB.

- Feedback mechanism need to be improved in order to facilitate employee's OCB.

- There must be reasonable autonomy given to employees in order to facilitate employee's OCB.

\section{Limitations of Study}

The limitations of the study include adapted questionnaire, small sample size, convenience sampling method, and survey based data collection method.

\section{References}

Bateman, T. S., \& Organ, a. D. (1983). Job satisfaction and the good soldier. The relationship between affect and employee citizenship. Academy of Management Journal, 587-595.

Chiu, S., \& Chen, H. (2005). Relationship between job characteristics and organizational citizenship behavior: The mediational role of job satisfaction. Social Behavior and Personality: An international journal, 33, 523-540.

DeVaro, J., Li, R., \& Brookshire, D. (2007). Analysing the job characteristics model: New support from a cross-section of establishments. The International Journal of Human Resource Management, 18(6), 986-1003.

Farh, J.-L., Podsakoff, P. M., \& Organ, D. W. (1990). Accounting for Organizational Citizenship Behavior: Leader Fairness and Task Scope versus Satisfaction. Journal of Management, 705-721

Hackman, J.R. \& Oldham, G.R. (1980). Work redesign. Reading, MA: Addison-Wesley 
Law, K. S., Wong, C. S., \& Chen, Z. G. (2005). The construct of organizational citizenship behaviour: Should we analyze after we have conceptualized?. In Handbook of organizational citizenship behaviour: A review of good soldier activity in organizations. Nova Science Publishers Inc.

Neuman, J. H., \& Baron, R. A. (1998). Workplace violence and workplace aggression: Evidence concerning specific forms, potential causes, and preferred targets. Journal of management, 24(3), 391-419.

Organ, D., \& Podsakoff, P. MacKenzie.(2006). Organizational citizenship behavior: Its nature, antecedents, and consequences.

Podsakoff, P. M. et al. (2000). Organizational citizenship behaviors: A critical review of the theoretical and empirical literature and suggestions for future research. Journal of Management, 26(3), 513-563.

Podsakoff, P. M., \& MacKenzie, S. B. (1997). Impact of organizational citizenship behavior on organizational performance: A review and suggestion for future research. Human performance, 10(2), 133-151.

Podsakoff, P. M., MacKenzie, S. B., \& Bommer, W. H. (1996). Transformational leader behaviors and substitutes for leadership as determinants of employee satisfaction, commitment, trust, and organizational citizenship behaviors. Journal of management, 22(2), 259-298.

Smith, C. A., Organ, D. W., \& Near, J. P. (1983). Organizational citizenship behavior: Its nature and antecedents. Journal of applied psychology, 68(4), 653. 